\title{
SHORT-TERM RESPONSE IN THE MICROBIAL FOOD WEB TO ORGANIC MATTER LOADING
}

\author{
1 Institute of Geography and Geoecology, \\ Berlin, Federal Republic of Germany \\ and \\ 2 Centrall Institute of Physical Chemistry \\ Berlin, Federal Republic of Germany
}

\begin{abstract}
A short-term experiment on the role of microbial food web in a eutrophic shallow lake is described. The results obtained demonstrate a high potential of the pelagic microbial food web (bacteria - Protozoa) to respond to disturbances in a balanced ecosystem.
\end{abstract}

\section{INTRODUCTION}

The role and function of the microbial web in marine ecosystems have been demon. strated since the beginning of the 1980 's (Azam et al. 1983). The microbial loop is now recognized as an important component of pelagic marine food webs. But also in lakes more than a half of the primary product may pass through bacterioplankton (Cole et al. 1988; Simon 1987). Rieman and Sondergaard (1986) presented results from oligotrophic and mesotrophic limnic ecosystems and reported a considerable carbon flux through the microbial food web. Although it is generally suggested that the microbial loop is also active in fresh waters, there is a lack of information from eutrophic freshwater ecosystems (Porter et al. 1985). Therefore, our paper aims at improving the knowledge on this part of the food web in a eutrophic shallow lake (Lake Müggelsee, Berlin). Rapid growth of the microbial components (bacteria and protozoans) was hoped to be induced by adding an easily decomposable substrate. The response of planktonic components to this organic matter influx was investigated.

\section{METHODS}

Lake Müggelsee is a eutrophic, polymictic shallow lake with an area of $7.2 \mathrm{~km}^{2}$ and a mean depth of about $4.9 \mathrm{~m}$. Tho response of planktonic components to an organic 
nutrient load was observed in enclosure experiments. Polyethylene bags (75 $\mathbb{1}$ each) filled with the lake water were used. To induce a rapid development of the microbial web, an extract of rice graine (about $100 \mathrm{mg} \mathrm{C} / \mathrm{dm}^{3}$ ) was added to one of the bags. The bags were incubated in the euphotic zone of Lake Müggelsee. The water within the bags was always very well mixed by wind-induced turbulence and was in permanent contact with the air. The following parameters and processes were measured and estimated daily for a week:

- dissolved inorganic and organic nutrients $\left(\mathbb{P O}_{4}, \mathbb{N O}_{3}, \mathbb{N H}_{4}, \mathrm{DIC}, \mathrm{DOC}, \mathrm{pH}\right.$, and alkalinity, according to standard procedures (Anonymus 1986);

- abundance of bacteria, by epilluorescence microscopy after staining with acridine orange (Zimmermann and Meyer-Reil 1974) and cell volume estimation under a scanning electron microscope (SEM);

- abundance of phytoplankton, by means of an inverted microscope and estimation of specific cell volume (Hoeg 1983);

- chlorophyll fluorescence, by means of a Turner fluorimeter;

- zooplankton (including protozoan components: heterotrophic flagellates, rhizo. pods, cilliates) abundance and biomass (Arndt and Nixdorf in press; Krocker 1987);

- primary production, measured by the conventional ${ }^{14}$ C-method (for details see Nixdorf 1985). After light incubation and filtration of the primary production samples,

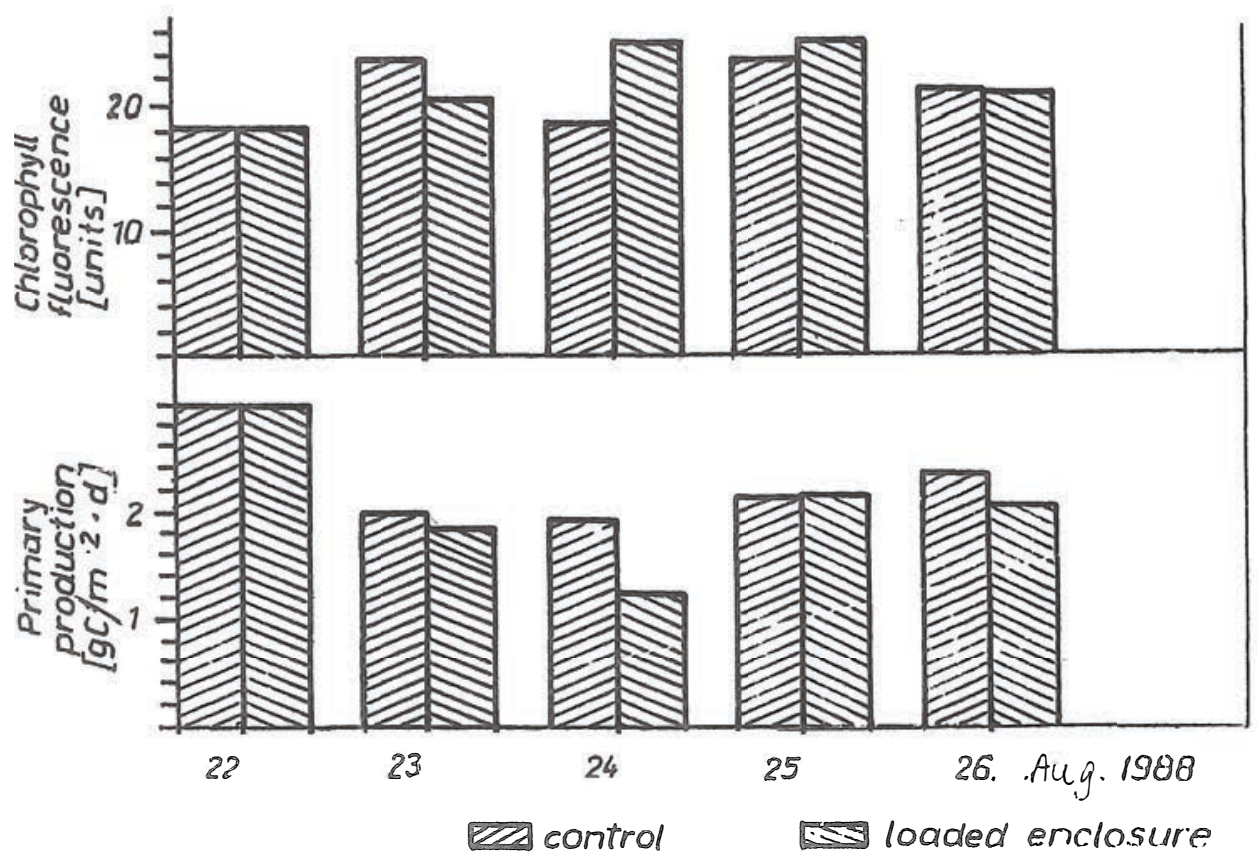

Fig. 1. Time course of Ifuorescence and primary production in the contiol and the loaded enclosures 
some of them were darkened as in Nixdorf and Fulda (1989) and incubated for $24 \mathrm{~h}$ in situ to estimate the dark carbon losses (DCL). These losses are caused by algal respiration during the dark period (night hours and residence time in the aphotic layer during the day) mainly;

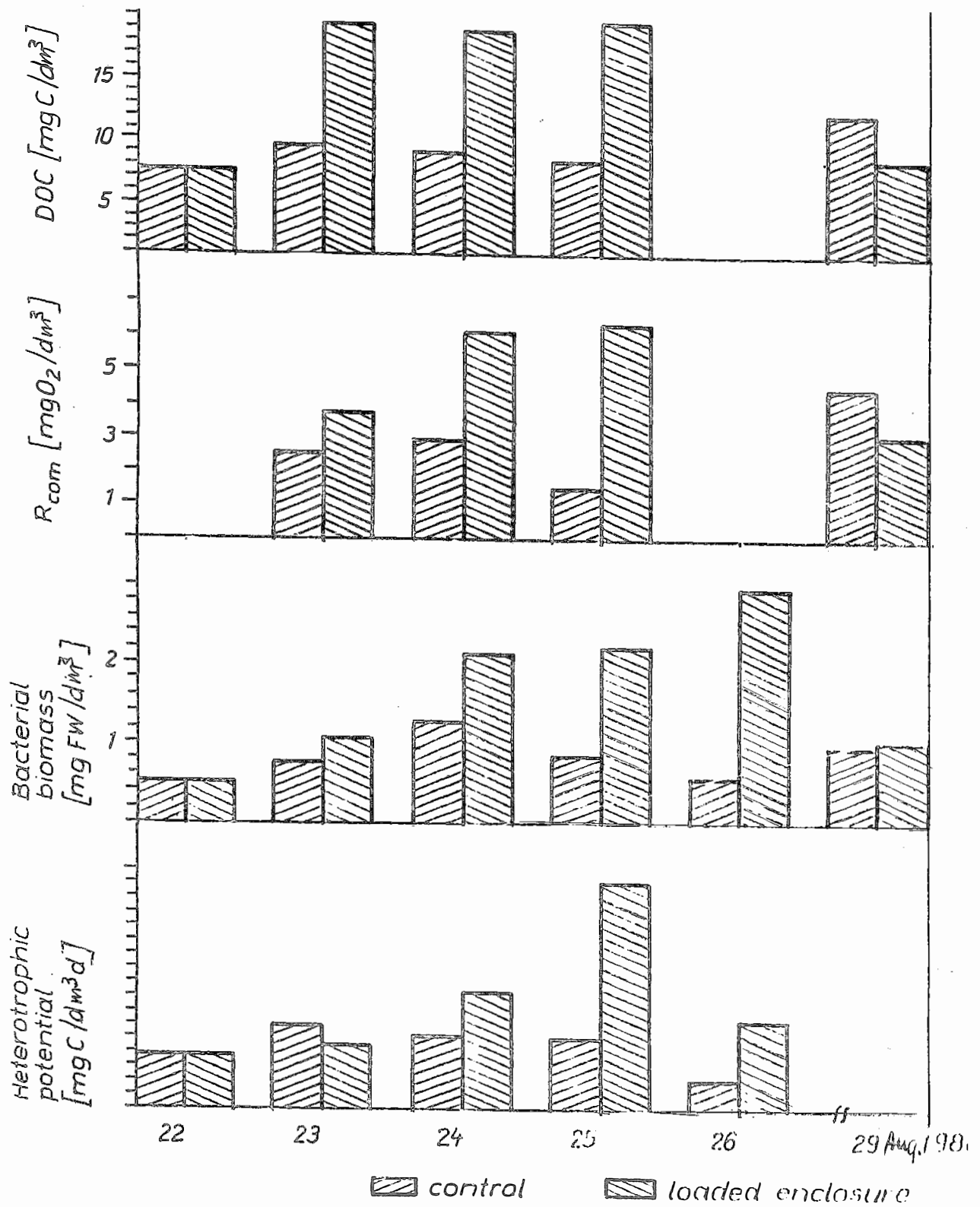

Fig. 2. Bacterial biomass and activity, community respiration and concentration of $D O C$ in the control and the loaded enclosure 
$-\mathrm{O}_{2}$-net community respiration $\left(\mathrm{R}_{\text {com }}\right)$, measured by Winkler titration (accuracy of $0.03 \mathrm{mg} \mathrm{O} / 2 \mathrm{dm}^{3}$ );

- heterotrophic activities, calculated from ${ }^{14} \mathrm{C}$-glucose uptake (Nixdorf in press) and feeding the dominant heterotrophic flagellate Anthophysa sp. with 1 um diameter latex beads (Arndt et al. in prep.).

\section{RESULTS AND DISCUSSION}

Chemical parameters varied little within the period of study from 22 to 29 August, no significant differences being recorded in most cases between the control and the organic matter-loaded enclosures. These parameters as well as the balance of phytoplankton and mesozooplankton seemed to be independent of the organic matter added. This is demonstrated in Fig. 1 where the fluorescence and algal primary production show no significant differences between the control and loaded enclosures.

Only a portion of the added rice extract was found in the dissolved organic carbon fraction (Fig. 2). As early as the next day after substrate addition, a bacterial popula-

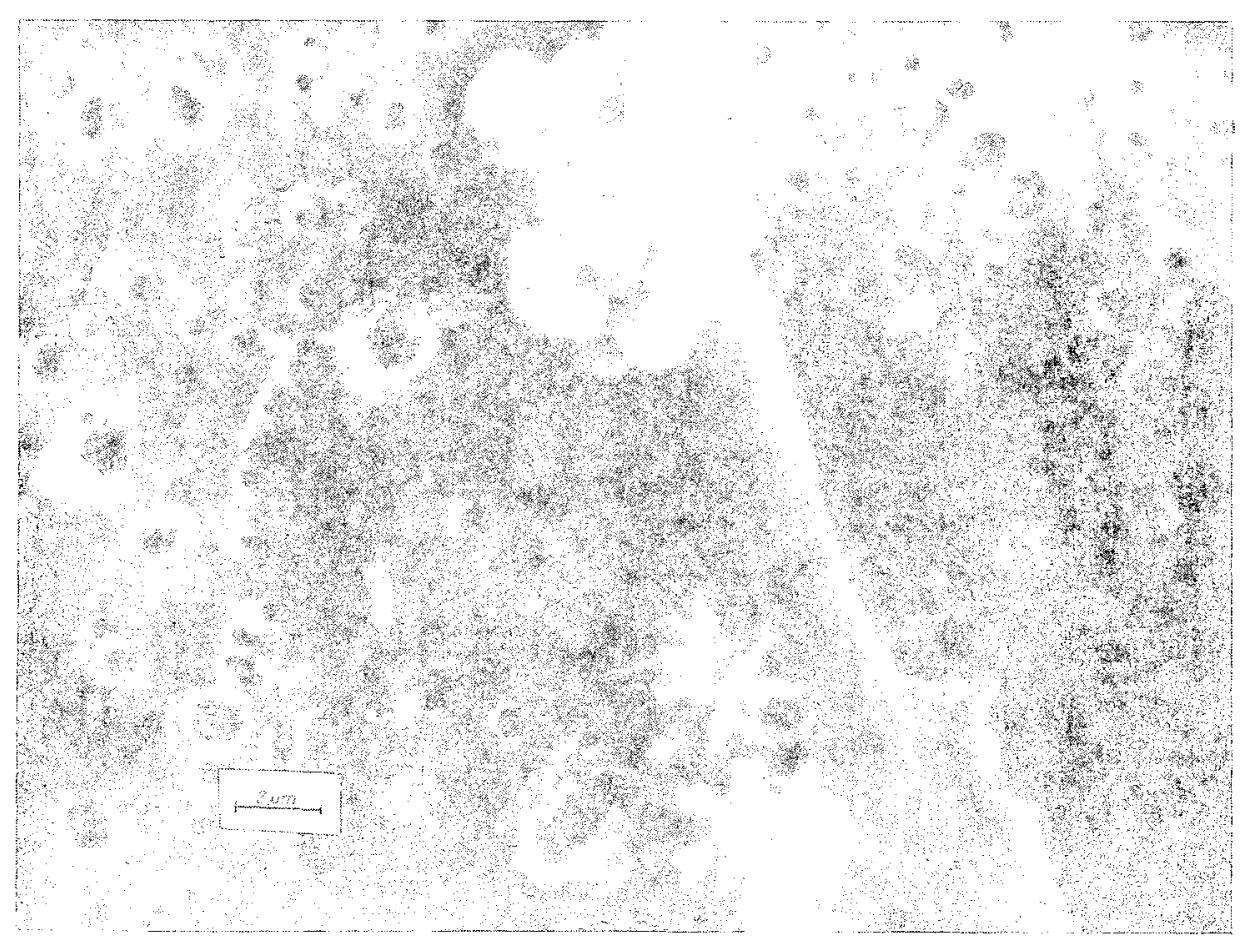

Fig. 3. Aggregates of bacteria attached to a filanentous blue-green algal cell in the loaded snclosure. Bacterionlankton was concentrated on Sartorius membane filters. 


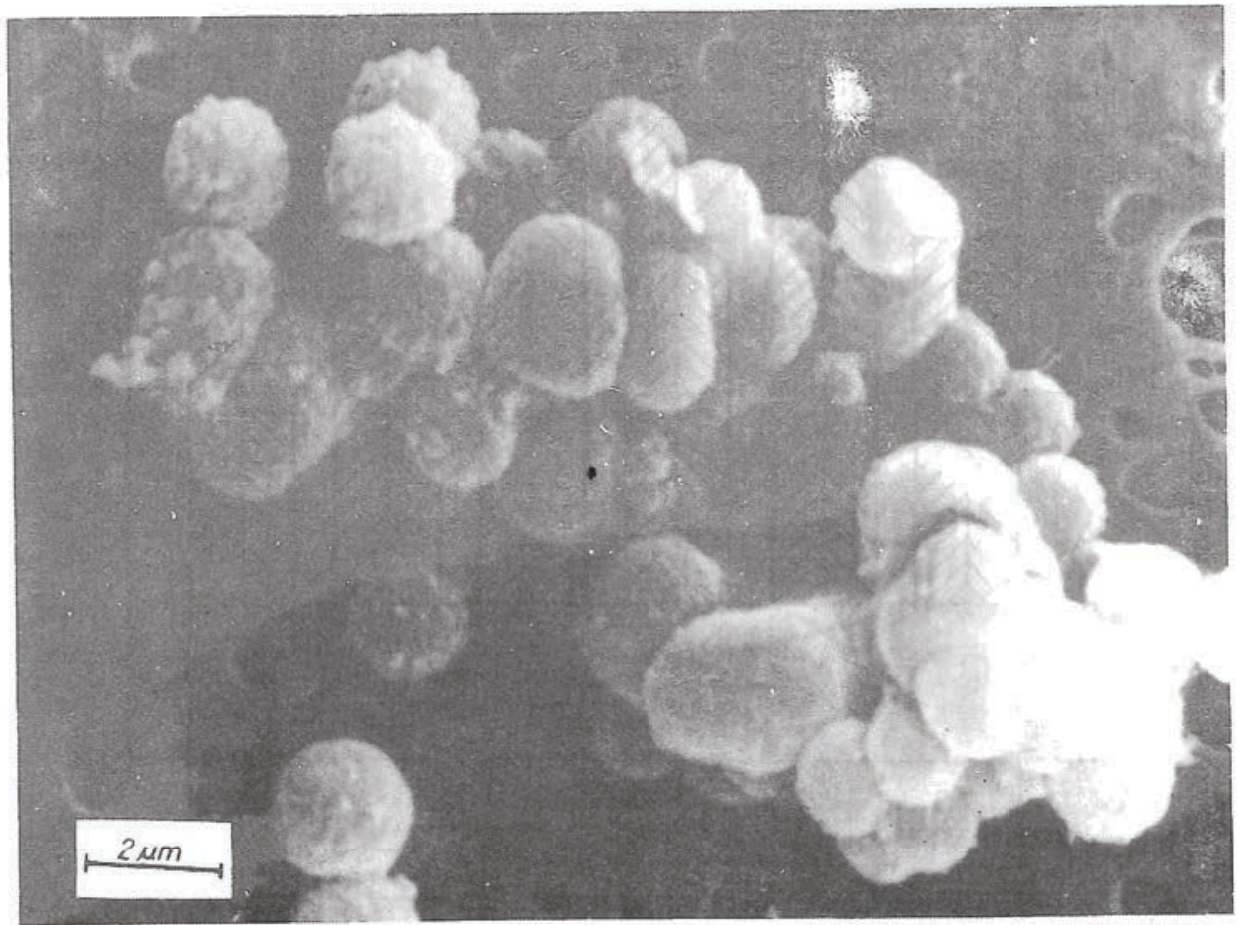

Fig. 4. Aggregates of bacteria which were typical fur the loaded enclosure

tion developed in the loaded enclosure, the population being morphologically and physiologically different from that in the control. We observed a sixfold increase in bacterial biomass (Fig. 2); the loaded enclosure showed also aggregates of bacteria which, as demonstrated by SEM (Figs 3 and 4), were not typical of the microplankton of Lake Müggelsee. Activity of the bacteria, measured as heterotrophic glucose uptake in the experimental enclosure, was enhanced in a similar range (Fig. 2).

The fate of the added organic matter was estimated from the destruction rate of organic matter. The community respiration and heterotrophic potential increased by the factor of 2-4 due to an intensive metabolism (Fig. 2).

The simulated increase in bacterial biomass was followed by a corresponding development of protozoans, especially small heterotrophic flagellates (SHF; Fig. 5). Measurements of the feeding rate of the heterotrophic flagellate Anthophysa sp. yielded values of 75 beads per flagellate per hour. Assuming that the flagellates take up both bacteria and the beads indiscriminately, we conclude that SHF control the entire bacterial biomass. Furthermore, this calculation indicates that the uptake rate measured has to be regarded as the maximum rate. 


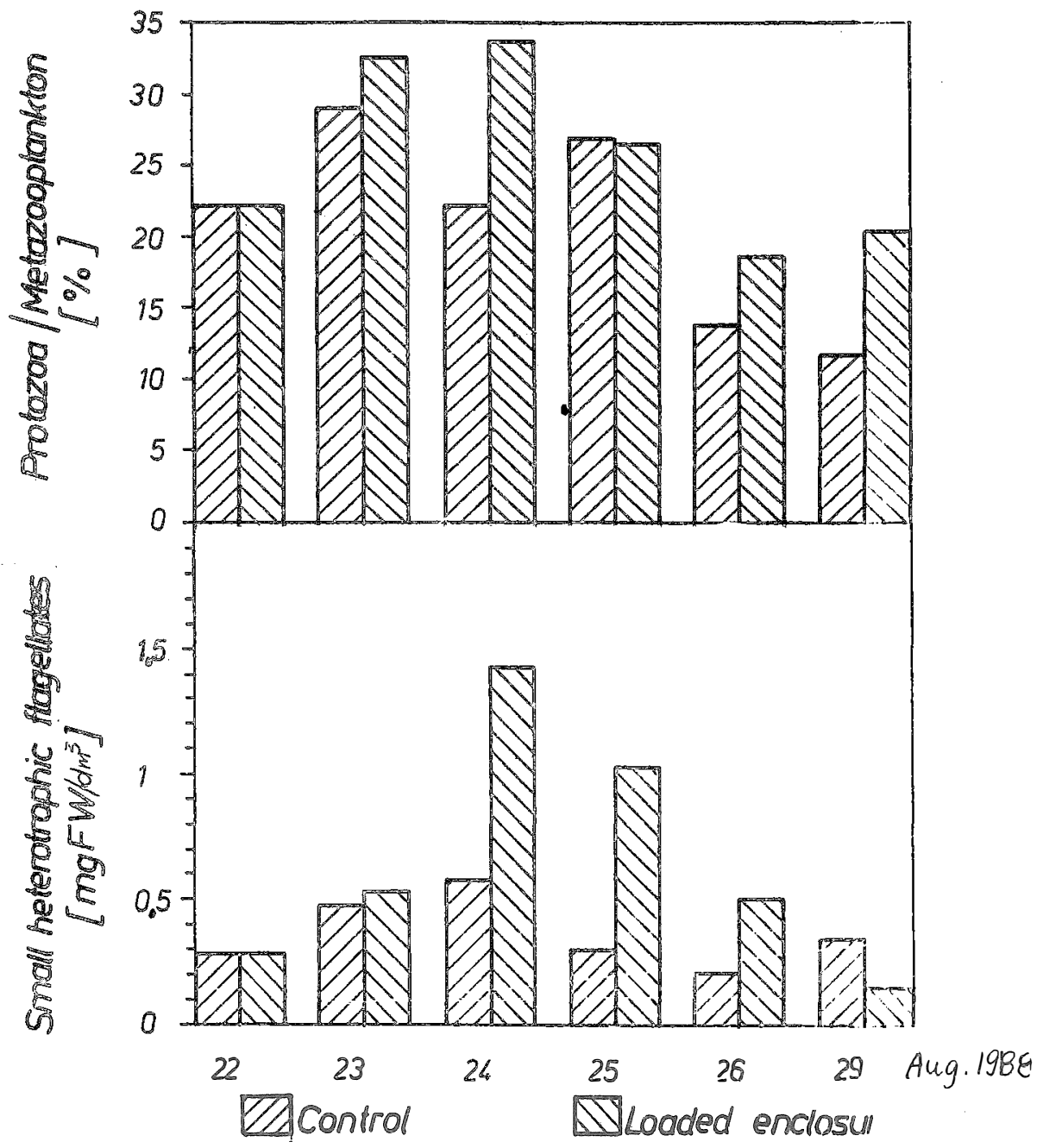

Fig. 5. Biomass of small heterotrophic flagellates (SHF) ane̊ their per cent contriounon ro metazooplankton

Both trophic levels showed close metabolic interactions. Fig. 6 shows the relationship between the SHF and bacterial biomasses. It is obvious that the increase in the SHF biomass does not follow changes in the bacterial biomass. From Day 3 of the experiment, the SHF enhancement was stopped, the flagellate biomass becoming reduced, al though the bacteria were developing rapidly until Day 4. It is assumed that the phenomenon is caused by grazing impact of other zooplankters such as heliozoans and metazoans. Those zooplankton groups were observed to feed on heterotrophic flagellates (Arndt and Nixdorf in press; Arndt unpubl. data) indicating a further control of the described interactions in the microbial food web by higher trophic levels. 


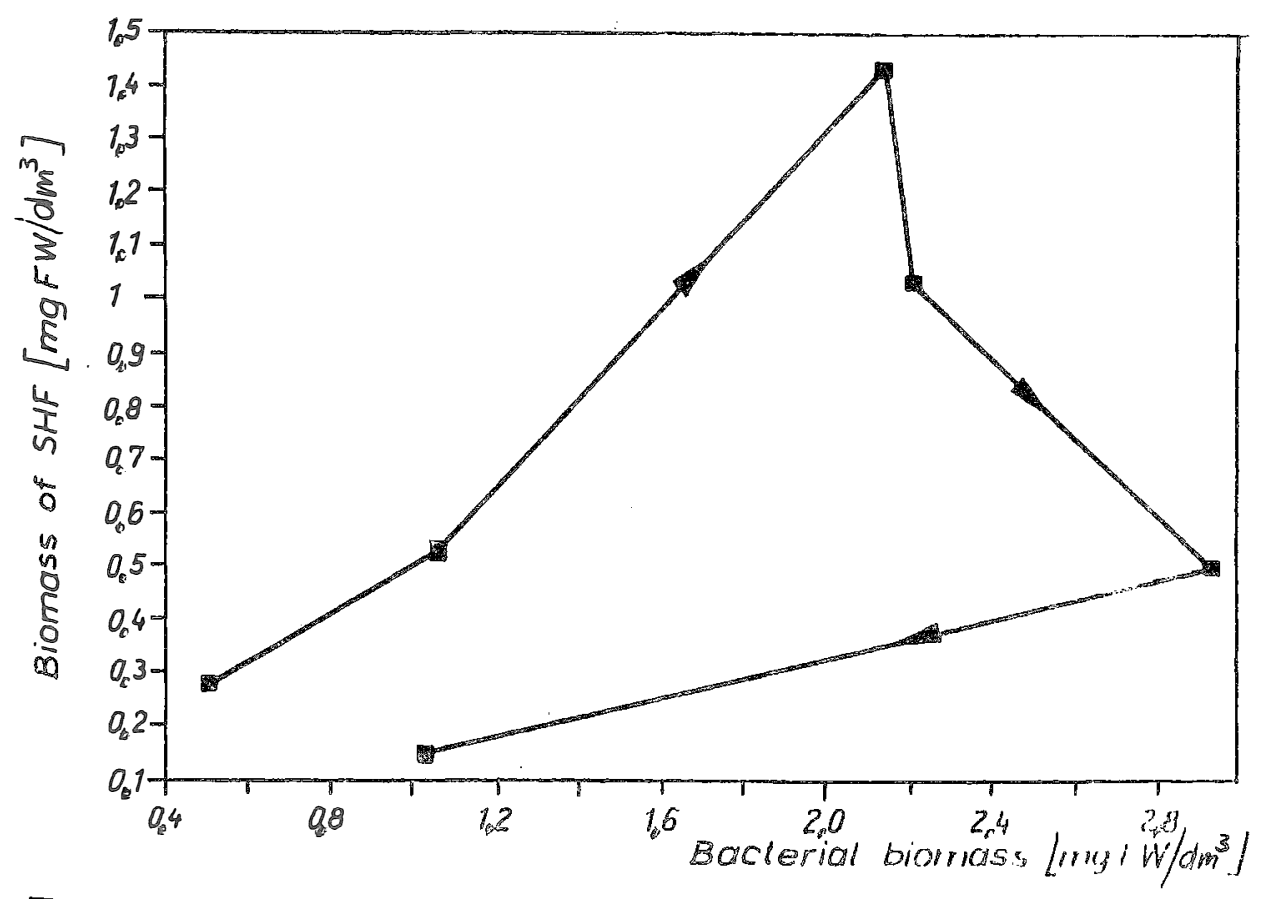

Fig. 6. Relationship between biomass of small heterotrophic flagellates and bacteria in the loaded enciosure

\section{CONCLUSIONS}

Our analysis of the initial experiments concerning the role of the microbial web in a eutrophic shallow lake revealed the following facts:

1. The results demonstrated a high ecological potential of the pelagic microbial food web (bacteria - Protozoa) to respond to disturbances in a balanced ecosystem. The total organic input was respired by the microbial community within one week.

2. The balance of phyto- and mesozooplankton was independent of the addition of organic matter during short-term experiments (days to one week).

3. The resulting high bacterial production induced a drastic increase in the Protozoa (mainly heterotrophic flagellates) which rapidly consumed this "overflow" production.

4. Our results point to the ecological role of the microbial web as a stabilizing factor in eutrophic ecosystems, capable of balancing the eutrophication process.

\section{ACKNOWLEDGEMENTS}

The experiments would have been impossible without the technical assistance of our colleagues Ingrid Hoffmann, Lilo Dollan, Bärbel Müller, and Doris Schneider. 
We also wish to thank Sigrid Hoeg for the estimation of phytoplankton biomass and Maria Krocker for estimating mesozooplankton biomass.

\section{REFERENCES}

Anonymus, 1986: Ausgewåhlte Methoden der Wasseruntersuchung. Bd. I. Gustav Fischer Verlag, Jena.

Azam Fo, T. Fenchel, J.G. Field, J.S. Gray, LoA. Meyer-Reil, F. Thingstad, 1983: The ecological role of water column microbes in the sea. Mar. Ecol. Prog. Ser., 10: 257-263.

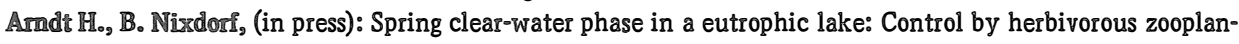
kton enhanced by grazing on components of the microbial web. Verh. Int. Verein Limnolo, 24.

Cole JoJog S. Findley, MoL. Pace, 1988: Bacterial production in fresh and saltwater ecosystems: a cross-system overview. Mar. Ecol. Progr. Ser., 43: 1-10.

Hoeg So, 1983: Ein Vergleich der Algenzönosen in Berliner Seen 1980. Acta hydrophys., 28: 255-272.

Krocker Mog 1987: Das Zooplankton des Grossen Müggelsees in den Jahren 1980-1984. Acta hydrophys., 31: $51-76$.

Nixdorf Bo, 1985: Photosynthetic activity of dominant algal species in eutrophic shallow lake (Grosser Müggelsee, Berlin) investigated by microautoradiography. Int. Rev. ges. Hydrobiol., 70: 237-246.

Nixdorf $\mathbb{B}_{\circ}$ (in press). The fate of phytoplankton primary production: Losses in relation to bacterial metabolism in a eutrophic shallow lake. Arch. Hydrobiol. Beih. Ergebn. Limnol.

Nixdorf Bo, Fulda S., 1989: A method for estimation of phytoplankton dark losses by application of ${ }^{14} \mathrm{C}$-technique. Arch. Hydrobiol. Beih. Ergebn. Limnol., 33: 345-350.

Porter K.G., E.B. Sherr, B.F. Sherr, M. Pace, R.W. Sanders, 1985: Protozoa in planktonic food webs. J. Protozool., 32: 409-415.

Rieman B., M. Sondergaard, 1986: Carbon dynamics in eutrophic temperate lakes. Elsevier. Amsterdam - New York, $284 \mathrm{pp}$.

Simon Mo, 1987: Biomass and production of small and large freeliving and attached bacteria in Lake Constance. Limnol. Oceanogr., 32: 591-607.

Zimamermann $\mathbb{R}_{0}$, L.A. Meyer-Reil, 1974: A new method for fluorescence staining of bacterial populations on membrane filters. Kieler Meeresforsch., 30: 24-27.

Author's addresses:

B. Nixdorf, H. Arndt

Institute of Geography and Geoecology

Department of Hydrology

Můggelseedamm 260

D-1162 Berlin

Federal Republic of Germany

E. Schierhorn

Central Institute of Physical Chemistry

Analytical Center

Rudower Chausse 5

D-1199 Berlin

Federal Republic of Germany 